\title{
ANALYTICAL METHODS FOR THE DETERMINATION OF LEVULOSE IN CRUDE PRODUCTS
}

\author{
By R. F. Jackson, J. A. Mathews, and W. D. Chase
}

ABSTRACT

In sequel to a previous article (RP426) detailed descriptions are presented of analytical methods for the determination of levulose in crude products. The polysaccharides in which levulose is the predominating sugar can be hydrolyzed for analytical purposes in 35 minutes at $80^{\circ} \mathrm{C}$. by $0.14 \mathrm{~N} \mathrm{HCl}$. After hydrolysis levulose is determined either by the selective copper reduction method or by polarization at two temperatures. The volume of the marc from a $50-\mathrm{g}$ sample of artichokes is found to be $0.8 \mathrm{ml}$. Rapid methods of titrating reducing sugars in low concentration are suggested in extension of the standard methods of Lane and Eynon. Methods of determining the purity of crude and purified juices are described. Applications of the methods of analysis are made to honey and fruits in most of which levulose is found to be the predominating sugar.

\section{CONTENTS}

I. Introductory

II. Hydrolysis of polysaccharides in artichoke juices..............

III. Accessory data .

1. Volume of marc and lead precipitate.....

2. The Mathews formula

3. Titration of reducing sugar in low concentration

4. Steffen's reagents

IV. Analytical procedure

1. Artichokes or similar products

(a) Preparation and hydrolysis of sample Nyns method

(c) Analysis by Lane and Eynon titration and temperature coefficient of polarization.....................

(d) Purity of diffusion or press juice...

(e) Notes

2. Exhausted pulp and pulp water (rapid method)

3. Levulate sludge

(a) Total $\mathrm{CaO}$

(b) Total sugar

(c) Levulose

4. Levulate cake

(a) Total $\mathrm{CaO}$

(b) Total sugar and levulose

5. Waste water

(a) $\mathrm{CaO}$

(b) Total sugar.

(c) Levulose

6. Evaporator liquors

(a) Dry substance

(b) Direct polarization and apparent purity

(c) Total sugar._...... 611

(d) True purity

V. Honey and various fruits

\section{INTRODUCTORY}

The wide distribution of levulose in natural and manufactured products makes desirable the formulation of a system of analysis for 
its quantitative determination. In a previous article ${ }^{1}$ some of the fundamental physical properties of pure levulose in aqueous solution and improved methods for its selective determination in sugar mixtures were described. In the present article we shall discuss the determination of levulose in crude natural products and particularly in the intermediate products obtained during the process of preparation of levulose from natural sources by the method described by Jackson, Silsbee, and Proffitt. ${ }^{2}$

In natural products levulose occurs in the form of the uncombined sugar or combined in the form of compound sugars or of polysaccharides. When it occurs as the free sugar it is invariably accompanied by dextrose and frequently by sucrose or other sugar. The polysaccharides which contain levulose have properties which make a direct determination of them at present impossible. They are, however, very easily hydrolyzed by dilute acids and may be determined indirectly by analysis of the products of hydrolysis. The reducing sugars formed by hydrolysis consist of levulose mixed with varying proportions of dextrose. The problems involved in analyzing sugar mixtures containing levulose become mainly questions of differentiation between levulose and dextrose since they practically always occur together.

It will be convenient to characterize these mixtures according to the ratio of levulose to total reducing sugar. Various methods of determining this ratio have been described in the previous article. It can be determined rigorously only by direct analysis for reducing sugar and selective analysis for levulose. In the former article a proximate method was described and designated the Mathews formula (RP426, p. 433) in which it was shown that the ratio could be determined conveniently by combining the direct polarization with the titration for total reducing sugar under the assumption that no optically active substances other than dextrose and levulose were present in the mixture. The Mathews ratio will sometimes be found valuable even when it differs from the true ratio, for the difference then becomes a measure of the optically active or reducing materials which are neither dextrose nor levulose.

In previous articles ${ }^{3}$ it has been shown that inulin yields upon acid hydrolysis about 5 per cent of a group of nonreducing difructose anhydrides which are of such high stability as to survive the hydrolysis. No analytical method has as yet been devised to determine these substances directly, since it is impossible to hydrolyze them without employing acid of such high concentration as to destroy the reducing sugar in the sample. In the analysis of juices of plants which contain inulin or similar polysaccharides these refractory disaccharides will escape detection under the ordinary procedure. If, however, we assume that they are mainly responsible for the deviations of the Mathews ratio from the true ratio under the assumption that levulose, dextrose, and the disaccharides are the only optically active substances present, we have a means of determining them approximately.

\footnotetext{
1 Jackson and Mathews, B. S. Jour. Research, vol. 8 (RP426), p. 403, 1932. Repeated reference will be made to Research Paper No. 426 which for brevity will be designated (RP426).

2 B. S. Sci. Paper No. 519, vol. 20, p. 604, 1926.

3 Jackson and Goergen, B. S. Jour. Research, vol. 3 (RP79), p. 27, 1929. Jackson and McDonald, B. S. Jour. Research, vol. 5 (RP251), p. 1151, 1930; vol. 6 (R P299), p. 709, 1931.
} 


\section{HYDROLYSIS OF POLYSACCHARIDES IN ARTICHOKE JUICES}

The juices contained in the roots of the Jerusalem artichoke, dahlia, chicory, and many other composite flowering plants are rich in polysaccharides in which levulose is the predominating sugar. In order to analyze these juices the conditions of acidity, temperature, and time must be found which will yield complete hydrolysis without destruction of the products of the reaction. The experiments described below were performed with the juices and pulp of the Jerusalem artichoke, but the conclusions are equally applicable to any juice or material which contains similar polysaccharides.

In order to determine the proper conditions for hydrolysis weighed quantities of the expressed juice or comminuted pulp of Jerusalem artichokes were introduced into $200 \mathrm{ml}$ Soxhlet flasks, diluted to about $175 \mathrm{ml}$, and acidified with 3 or $4 \mathrm{ml}$ of $8 \mathrm{~N} \mathrm{HCl}$. The flasks were immersed in a water bath maintained at either $70^{\circ}$ or $80^{\circ} \mathrm{C}$. and after selected intervals of time were one by one removed and the contents cooled rapidly. To simplity the procedure the solutions were allowed to assume the temperature of the bath without agitation.

TABLE 1.-Hydrolysis of artichoke pulp with hydrochloric acid

( 3 or $4 \mathrm{ml}$ of $8 \mathrm{~N} \mathrm{HCl}$ added to $175 \mathrm{ml}$ of solution)

(a) 10-g SAMPLE, $4 \mathrm{ml} \mathrm{HCl,} 80^{\circ} \mathrm{C}$.

\begin{tabular}{|c|c|c|c|c|}
\hline $\begin{array}{l}\text { Time of } \\
\text { hydroly- } \\
\text { sis }\end{array}$ & $\begin{array}{l}\text { Reduc- } \\
\text { ing } \\
\text { sugars }\end{array}$ & $\begin{array}{l}\text { Levu- } \\
\text { lose }\end{array}$ & $\begin{array}{c}\begin{array}{c}\text { Ratio: } \\
\text { levulose }\end{array} \\
\begin{array}{c}\text { reducing } \\
\text { sugar }\end{array}\end{array}$ & $\begin{array}{l}\text { Mathews } \\
\text { ratio: } \\
\text { levulose } \\
\begin{array}{c}\text { reducing } \\
\text { sugar }\end{array}\end{array}$ \\
\hline $\begin{array}{c}\text { Minutes } \\
10 \\
20 \\
30 \\
40 \\
60\end{array}$ & $\begin{array}{c}\text { Per cent } \\
16.74 \\
17.00 \\
17.20 \\
17.14 \\
17.36\end{array}$ & $\begin{array}{l}\text { Per cent } \\
12.45 \\
12.43 \\
12.53\end{array}$ & $\begin{array}{l}\text { Per cent } \\
72.4 \\
72.5 \\
72.2\end{array}$ & $\begin{array}{r}\text { Per cent } \\
67.9 \\
68.8 \\
67.4\end{array}$ \\
\hline
\end{tabular}

(b) 10-g SAMPLE, $4 \mathrm{ml} \mathrm{HCl,} 70^{\circ} \mathrm{C}$.

\begin{tabular}{|c|c|c|c|c|}
\hline 19 & 16.90 & & & \\
\hline $\begin{array}{l}30 \\
42\end{array}$ & $\begin{array}{l}17.06 \\
17.10\end{array}$ & 12.45 & 72.8 & \\
\hline 50 & 17.11 & 12.23 & 71.5 & 70.3 \\
\hline 60 & 17.16 & 12.54 & 73.1 & 69.5 \\
\hline
\end{tabular}

(c) 50-g SAMPLE, $4 \mathrm{ml} \mathrm{HCl,} 80^{\circ} \mathrm{C}$.

\begin{tabular}{|l|l|l|r|r|}
\hline 20 & 17.20 & & & \\
30 & 17.20 & 12.80 & 74.4 & 71.9 \\
41 & 17.30 & 12.72 & 73.5 & 71.2 \\
52 & 17.36 & 12.71 & 73.2 & 70.9 \\
63 & 17.38 & 12.69 & 73.0 & 69.8 \\
\hline
\end{tabular}

(d) 50-g SAMPLF, $4 \mathrm{ml} \mathrm{HCl,} 70^{\circ} \mathrm{C}$.

\begin{tabular}{|c|c|c|c|c|}
\hline $\begin{array}{l}\text { Time of } \\
\text { hydroly- } \\
\text { sis }\end{array}$ & $\begin{array}{l}\text { Reduc- } \\
\text { ing } \\
\text { sugars }\end{array}$ & $\begin{array}{l}\text { Levu- } \\
\text { lose }\end{array}$ & $\begin{array}{c}\begin{array}{c}\text { Ratio: } \\
\text { levulose }\end{array} \\
\begin{array}{c}\text { reducing } \\
\text { sugar }\end{array}\end{array}$ & $\begin{array}{l}\text { Mathews } \\
\text { ratio: } \\
\text { levulose } \\
\text { reducing } \\
\text { sugar }\end{array}$ \\
\hline $\begin{array}{c}\text { Minut es } \\
20 \\
30 \\
40 \\
50 \\
70\end{array}$ & $\begin{array}{c}\text { Per cent } \\
17.25 \\
17.28 \\
17.26 \\
17.23 \\
17.18\end{array}$ & $\begin{array}{l}\text { Per cent } \\
12.64 \\
12.84 \\
12.90\end{array}$ & $\begin{array}{r}\text { Per cent } \\
73.2 \\
74.5 \\
75.1\end{array}$ & $\begin{array}{r}\text { Per cent } \\
72.1 \\
72.5 \\
72.6\end{array}$ \\
\hline
\end{tabular}

(e) 50-g SAMPLE, $4 \mathrm{ml} \mathrm{HCl,} 80^{\circ} \mathrm{C}$.

\begin{tabular}{|r|r|r|r|r|}
\hline 7 & 11.29 & & & 84.0 \\
20 & 17.10 & 14.43 & 84.4 & 84.1 \\
30 & 17.04 & 14.30 & 83.9 & 83.7 \\
60 & 16.96 & 14.16 & 83.5 & 82.4 \\
90 & 17.19 & 14.39 & 83.7 & 80.7 \\
\hline
\end{tabular}

(f) 50-g SAMPLE, $3 \mathrm{ml} \mathrm{HCl,} 80^{\circ} \mathrm{C}$.

\begin{tabular}{|l|l|l|l|l|}
\hline 10 & 14.44 & & & 82.9 \\
20 & 17.30 & 14.86 & 85.9 & 83.7 \\
30 & 17.31 & 14.64 & 84.6 & 83.9 \\
60 & 17.41 & 14.61 & 83.9 & 83.9 \\
90 & 17.42 & 14.65 & 84.1 & 83.1 \\
\hline
\end{tabular}

The samples of pulp were prepared by passing artichoke tubers through a food chopper, the plate of which had perforations $2 \mathrm{~mm}$ in diameter. The hydrolysis experiments were conducted with 10-g and with $50-\mathrm{g}$ samples. Ten grams is a sufficient quantity if the sugar analysis is made solely by copper reduction methods, while a $50-\mathrm{g}$ sample is preferable if the procedure includes a polariscopic 
determination. In the series here described all samples, including the 10-g samples, were polarized, analyzed for total reducing sugar by Lane and Eynon's volumetric method, and selectively analyzed for levulose by Jackson and Mathews's modification of Nyns's method (RP426, p. 425).

The samples after cooling were neutralized and defecated with a saturated solution of normal lead acetate. The addition of alkali was made slowly and with agitation vigorous enough to obviate momentary local alkalinity. The solutions were finally made to volume and filtered. The filtrates were polarized in a $400-\mathrm{mm}$ tube and an aliquot volume was analyzed for total reducing sugar and levulose.

The experimental results are shown in Table 1. Upon examination of the individual series it becomes apparent that regardless of changed conditions of hydrolysis the respective samples arrive at approximately constant compositions after relatively short periods of time. Even when the time is greatly extended there is no evidence of decomposition of the products of hydrolysis. Indeed, in many instances there appears to be a slight increase in total sugar, possibly by gradual hydrolysis of the difructose anhydrides. Table 1 (f) shows that $3 \mathrm{ml}$ of $\mathrm{HCl}$ is about as effective as the $4 \mathrm{ml}$ used in the other experiments and produces complete hydrolysis in about the same period of time. This can be explained by the fact that the determining factor is the time required to attain the bath temperature and that the hydrolysis itself proceeds very rapidly in either concentration of acid.

The deviations from constancy of the individual determinations are in many cases greater than the experimental error of analysis. These errors arise probably from the difficulty of obtaining complete concentration equilibrium between the solution and the suspended pulp. The divergences diminish, as shown in Table 2, when samples of press juice are hydrolyzed for periods of time between 25 and 60 minutes, although here again there is evidence of gradual hydrolysis of the disaccharides.

The Mathews ratio given in the last column of the tables will be discussed in a later paragraph.

On account of the relative uniformity of all the experimental results the selection of specifications is in a measure arbitrary. Although the hydrolysis can be completed rapidly at $70^{\circ}$, the defecation and filtration of solutions hydrolyzed at $80^{\circ}$ were more satisfactory.

Evidently $3 \mathrm{ml}$ of $8 \mathrm{~N} \mathrm{HCl}$ affords sufficient acidity for the samples under investigation. Conceivably samples of greater dry substance concentration might by buffer action greatly diminish the converting power of the hydrochloric acid. The juices upon which the experiments were made contained by refractometric estimation 17 to 20 per cent dry substance. A 50-g sample therefore contained 8.5 to $10 \mathrm{~g}$ of total solids. In order to ascertain how great a variation in dry substance can be tolerated, further experiments were made on a press juice in which the hydrolysis was effected by $3 \mathrm{ml}$ of $8 \mathrm{~N} \mathrm{HCl}$ for 30 minutes at $80^{\circ} \mathrm{C}$., while the weight of sample was varied from 50 to $160 \mathrm{~g}$. In Table 3 are shown the polariscopic readings of the samples diluted after hydrolysis to a uniform concentration. The solutions containing $50 \mathrm{~g}$ and $80 \mathrm{~g}$ showed identical polarizations, and the one containing $100 \mathrm{~g}$ of sample showed but slightly lower polarization. The experiments indicate that the conditions selected for hydrolysis are 
valid even if the dry substance is increased nearly 100 per cent. Such a range of concentrations is great enough for the analysis of all naturally occurring juices, or more specifically, for samples which contain not in excess of $19 \mathrm{~g}$ of dry substance. In case of uncertainty the volume of $8 \mathrm{~N} \mathrm{HCl}$ can safely be increased to $4 \mathrm{ml}$.

TABLE 2.-Hydrolysis of artichoke press juice with hydrochloric acid

(50 $\mathrm{g}$ juice, $4 \mathrm{ml} 8 \mathrm{NHCl}, 80^{\circ} \mathrm{C}$.)

\begin{tabular}{|c|c|c|c|c|}
\hline $\begin{array}{c}\text { Time of } \\
\text { hydrolysis }\end{array}$ & $\begin{array}{c}\text { Reducing } \\
\text { sugars }\end{array}$ & Levulose & $\begin{array}{c}\text { Ratio: } \\
\text { levulose } \\
\text { reducing } \\
\text { sugar }\end{array}$ & $\begin{array}{c}\text { Mathews } \\
\text { ratio: } \\
\text { levulose } \\
\text { reducing } \\
\text { sugar }\end{array}$ \\
\hline Minutes & Per cent & Per cent & Per cent & Per cent \\
10 & 17.73 & 15.25 & 86.0 & 82.4 \\
25 & 17.78 & 15.26 & 85.8 & 82.6 \\
40 & 17.82 & 15.25 & 85.8 & 82.7 \\
60 & 17.83 & 15.33 & 86.0 & 82.7 \\
90 & 17.91 & 15.38 & 85.9 & 82.7 \\
\hline
\end{tabular}

TABLE 3.-Buffer action of arichoke juice, 19.8 brix ( $3 \mathrm{ml} 8 \mathrm{~N} \mathrm{HCl}, 30$ minutes, $80^{\circ} \mathrm{C}$.)

\begin{tabular}{|c|c|c|}
\hline $\begin{array}{l}\text { Weight of } \\
\text { press juice }\end{array}$ & $\begin{array}{l}\text { Polariza- } \\
\text { tion at con- } \\
\text { centration } \\
25 \mathrm{~g} \text { per } \\
100 \mathrm{ml} \\
\times(-1)\end{array}$ & $\begin{array}{l}\text { Relative } \\
\text { hydrolysis }\end{array}$ \\
\hline $\begin{array}{c}g \\
50 \\
80 \\
100 \\
125 \\
.160\end{array}$ & $\begin{array}{l}{ }^{\circ} S . \\
35.7 \\
35.7 \\
35.6 \\
30.9 \\
18.9\end{array}$ & $\begin{array}{c}\text { Per cent } \\
100.0 \\
100.0 \\
99.7 \\
86.7 \\
52.9\end{array}$ \\
\hline
\end{tabular}

\section{ACCESSORY DATA}

\section{VOLUME OF MARC AND LEAD PRECIPITATE}

When a $50-\mathrm{g}$ sample of pulped artichokes has been digested and defecated in preparation for analysis the residual marc and lead precipitate appear very voluminous. To determine the total volume displaced a sample was hydrolyzed and defecated in a weighed and calibrated 200-ml flask and the total mixture weighed after being made to volume. After thorough mixing, a small "catch" sample, about 25 to $30 \mathrm{~g}$, was weighed, made to $200 \mathrm{ml}$, and filtered. The remainder of the sample was filtered and a 25.00-ml aliquot sample made to 200 $\mathrm{ml}$. The latter and the filtrate from the weighed out sample were titrated in triplicate for total reducing sugar.

If $F$ is Lane and Eynon's factor, $T$ and $T^{\prime}$ the titers, respectively, of the aliquot and the "catch" sample, $V$ the calibrated volume of the 200-ml flask, $v$ the volume of the marc and precipitate, $W$ the total weight of the hydrolyzed and defecated sample made to $200 \mathrm{ml}$, and $w$ the weight of the "catch" sample, then

$$
\frac{F V(V-v)}{25 T}=\frac{F\left(V-\frac{v w}{W}\right) W}{T^{\prime} w}
$$


in which both terms express the total sugar in $50 \mathrm{~g}$ of the sample. All quantities are directly observed except $v$.

Two determinations yielded the values 0.802 and $0.856 \mathrm{ml}$ for the volume of the marc and precipitate, the difference being within the error of analysis. We shall accept the value $0.8 \mathrm{ml}$ for the marc of a $50-\mathrm{g}$ sample. The volume of the marc of a $10-\mathrm{g}$ sample will therefore be about $0.2 \mathrm{ml}$.

It is of interest to compare this value with the volume of the marc from the hot water digestion of the sugar beet. A 26-g sample of the latter defecated with basic lead acetate yields a volume of $0.6 \mathrm{ml}$, while a similar sample of artichoke pulp would occupy a volume of $0.43 \mathrm{ml}$.

\section{THE MATHEWS FORMULA}

In the previous article (RP426, p. 433) a formula was derived for the calculation of the ratio $(R)$ of levulose to total sugar in pure mixtures from the direct polarization and Lane and Eynon titration. This formula states that

$$
R=f\left(\frac{P T}{M^{2} D}\right)
$$

in which $P$ is the direct polarization, $T$ the corrected Lane and Eynon titer, and $D$ the number of volumes to which one volume of the solution polarized is diluted for titration. A graphic solution of the function yielded a single table from which all values of $R$ could be read o interpolated.

The Mathews ratio has been compared with the true ratio in all products which have been analyzed during the present investigation. In some instances because the measurements required for its solution can be made with higher precision, it has proved more serviceable than the ratio determined rigorously. In other instances a considerable discrepancy has appeared.

The discrepancy between the two ratios is significant, for it becomes an indication of the presence of optically active or of reducing substances which are not levulose or dextrose. In special cases the specific rotations of substances accompanying levulose and dextrose in natural products are known and can be employed for quantitative estimation. Thus, if $c$ is the saccharimetric normal weight (derived from the inverse ratio of the specific rotations of sucrose and of the substance in question), $V$ the volume in which $g$ grams of the sample was dissolved for polarization, $T$ the Lane and Eynon titer, $D$ the number of volumes to which one volume of the solution polarized was diluted for titration, and $\Delta R$ the difference between the true ratio and the Mathews ratio

$$
\frac{V c D \Delta R}{100 g T}=\text { per cent optical impurity }
$$

In many natural products it is not to be expected that the formula yields an accurate measure of a definite substance. It is rather a measure of all substances which are not dextrose or levulose, arbitrarily grouped together and estimated as a definite substance which is known to be present, but can not be selectively determined. Applications of the Mathews formula will be made in the analyses reported below. 


\section{TITRATION OF REDUCING SUGAR IN LOW CONCENTRATION}

The convenience and precision of Lane and Eynon's volumetric procedure ${ }^{4}$ suggest the desirability of extending the range of concentrations of sugar to greater dilutions in order to permit the rapid analysis of sweet waters, exhausted pulp from the diffusion battery, and, in general, any solution of low sugar concentration. Since at the end of Lane and Eynon's titration the concentration of cupric copper is very small, it is evident that the sharpness of the end point is independent of the initial concentration of copper. We can therefore take for titration smaller concentrations of copper than Lane and Eynon specified for their standard methods and still expect the same definiteness of end point, bearing in mind, however, that the slight excess of sugar required to reduce the methylene blue becomes an increasingly large proportion of the total titer as the amount of copper is diminished. It is consequently essential that the volume of indicator be constant for both standardization and analysis.

Lane and Eynon have shown that $5 \mathrm{ml}$ of the alkaline tartrate constituent of Soxhlet's solution is sufficient to keep the cupric copper in solution even for titrations as great as $50 \mathrm{ml}$. This concentration of tartrate has been retained in the following experiments. The copper solution has been diminished to $2.5 \mathrm{ml}$ and to $1.0 \mathrm{ml}$, respectively, and water added to make the total volume $10 \mathrm{ml}$.

The success of the method depends more upon the skill of the analyst than in the case of the standard methods. In order to perceive the end point more precisely we have altered the standard procedure of Lane and Eynon. Ten milliliters of the mixed dilute Soxhlet reagent was transfered to a $150-\mathrm{ml}$ flask. Somewhat less than the total volume of the sugar solution required to reduce the copper was added, and the flask being held with wooden tongs, the reaction mixture was brought to boiling during continuous agitation over a low free flame. Boiling was continued for one-half minute, the indicator was added, and the titration completed in the usual manner. This procedure permits a close perception of the end point.

The titrations against the solutions containing $2.5 \mathrm{ml}$ of copper solution proved to be about as reproducible as those by the standard methods. The factors for varying ratios of levulose to total sugar and varying titers are given in Table 4 . The analyst should always standardize his own procedure by titration of a known solution. The deviation of the factor from the tabulated factor found by experiment can safely be considered constant throughout the table.

TABLE 4.-Lane and Eynon factors for 10-ml Soxhlet solution composed of $2.5 \mathrm{ml}$ copper-sulphate solution, $2.5 \mathrm{ml}$ water, and $5 \mathrm{ml}$ alkaline tartrate

(Indicator, 1 drop of 1 per cent methylene blue)

\begin{tabular}{|c|c|c|c|c|c|c|c|c|c|c|c|}
\hline $\begin{array}{r}\mathrm{R} \\
\text { Titer }\end{array}$ & $\begin{array}{c}\text { Dex- } \\
\text { trose } \\
0\end{array}$ & 10 & 20 & 30 & 40 & $\begin{array}{c}\text { Invert } \\
\text { sugar } \\
50\end{array}$ & 60 & 70 & 80 & 90 & $\begin{array}{c}\text { Levu- } \\
\text { lose } \\
100\end{array}$ \\
\hline$m l$ & & & & & & & & & & & \\
15 & 26.2 & 26.3 & 26.4 & 26.5 & 26.6 & 26.8 & 26.9 & 27.0 & 27.1 & 27.2 & 27.3 \\
20 & 26.4 & 26.5 & 26.6 & 26.7 & 26.8 & 26.9 & 27.0 & 27.1 & 27.2 & 27.3 & 27.4 \\
25 & 26.5 & 26.6 & 26.7 & 26.9 & 27.0 & 27.1 & 27.2 & 27.3 & 27.4 & 27.5 & 27.6 \\
30 & 26.7 & 26.8 & 26.9 & 27.0 & 27.1 & 27.2 & 27.3 & 27.4 & 27.5 & 27.7 & 27.8 \\
40 & 27.0 & 27.1 & 27.2 & 27.3 & 27.4 & 27.5 & 27.7 & 27.8 & 27.9 & 28.0 & 28.1 \\
50 & 27.3 & 27.4 & 27.5 & 27.6 & 27.8 & 27.9 & 28.0 & 28.1 & 28.2 & 28.3 & 28.4 \\
\hline
\end{tabular}

$F=25.74+0.0317 T+0.0107 R$, in which $T$ is titer, and $R$ the ratio of levulose to total sugar expressed in per cent.

J. Soc. Chem. Ind., vol. 42, p. 32, 1923. 
The titrations against Soxhlet solutions containing $1 \mathrm{ml}$ of coppersulphate solution were, as expected, less reproducible than those against the standard Soxhlet solutions. The method can, however, be relied upon probably within 1 or 2 per cent of the quantity measured. Within the errors of titration the factor proved to be sensibly constant for variations of sugar concentration and composition. The mean of 7 titrations (indicator, 1 drop of 0.2 per cent methylene blue) yielded a value of the factor of 11.7.

The employment of solutions containing $2.5 \mathrm{ml}$ of copper sulphate in the Soxhlet solution permits the titration of solutions containing from 55 to $180 \mathrm{mg}$ of hexoses per $100 \mathrm{ml}$. Soxhlet solutions containing $1.0 \mathrm{ml}$ of copper cover a range of 23 to $78 \mathrm{mg}$ in $100 \mathrm{ml}$.

\section{STEFFEN'S REAGENTS}

Many of the intermediate products encountered in the production of levulose by the levulate process require a determination of alkalinity expressed as $\mathrm{CaO}$. For this purpose it is convenient to employ the Steffen reagents which are used in the beet-sugar industry. One milliliter of these solutions which are $1.786 \mathrm{~N}$ is equivalent to $0.05 \mathrm{~g}$ $\mathrm{CaO}$. Steffen's $\mathrm{HNO}_{3}$ and $\mathrm{NaOH}$ are suitable for the determination of total $\mathrm{CaO}$ by the usual method. To these are added hydrochloric acid and potassium oxalate of the same normality. For convenience they also are called Steffen's reagents and are useful for the neutralization and removal of calcium in the preparation of samples for sugar analysis. These solutions are all of equivalent concentration and consequently the amount of $\mathrm{CaC}_{2} \mathrm{O}_{4} . \mathrm{H}_{2} \mathrm{O}$ which is precipitated is related definitely to the volume of Steffen's reagents added. For each milliliter of Steffen's reagent $0.13 \mathrm{~g}$ of calcium oxalate is precipitated, and if the density of the precipitate is considered $2.05^{5}$ the volume displaced is $0.064 \mathrm{ml}$. The product of 0.064 and the volume of Steffen's oxalate added is the volume displaced by the precipitate.

Calcium oxalate is occasionally difficult to separate by filtration when precipitated from cold solutions. For removing both calcium and lead a mixture of $77.8 \mathrm{~g}$ of $\mathrm{K}_{2} \mathrm{HPO}_{4}$ and $82.2 \mathrm{~g}$ of $\mathrm{K}_{2} \mathrm{C}_{2} \mathrm{O}_{4} \cdot \mathrm{H}_{2} \mathrm{O}$ made to 1 liter is particularly satisfactory. This mixture has the same total normality as Steffen's reagents. The mean density of the precipitate is $2.19,{ }^{6}$ and the volume of precipitate from $1 \mathrm{ml}$ of reagent is $0.065 \mathrm{ml}$.

The volume displaced by the calcium precipitate can be calculated and deducted from the volume of the volumetric flask. It simplifies the subsequent calculation, however, to add by means of a graduated pipette a volume of water above the mark of the flask equal to the volume of the precipitate. This procedure is adopted for the methods suggested below.

\section{ANALYTICAL PROCEDURE}

\section{ARTICHOKES OR SIMILAR PRODUCTS}

The total reducing sugar in these products can be determined by Lane and Eynon titration and the levulose either by the modified Nyns method or by polarization at two temperatures.

5 Calculated from data in Handbook of Chemistry and Physics, 13th ed. Chemical Bulletin Publishing Co., p. 190, 1928.

Seo footnote 5. 
(a) PREPARATION AND HYDROLYSIS OF SAMPLE

Unless the substance is already fluid or finely divided, comminute the material in a food chopper or similar appliance and mix the sample thoroughly. Transfer a weighed sample (the amount depending upon the method of analysis selected) to a $200-\mathrm{ml}$ Soxhlet flask and add water to about $175 \mathrm{ml}$. Add $3 \mathrm{ml}$ of $8 \mathrm{~N} \mathrm{HCl}$, digest in a water bath at $80^{\circ} \mathrm{C}$. for 35 minutes. Cool and add a saturated solution of normal lead acetate (about $1 \mathrm{ml}$ for a 7 to $10 \mathrm{~g}$ sample and 3 to $6 \mathrm{ml}$ for a $50 \mathrm{~g}$ sample). Add $2.9 \mathrm{ml}$ of $8 \mathrm{~N} \mathrm{NaOH}$ with very vigorous agitation, avoiding any local alkalinity. Make to volume, mix thoroughly, and allow to stand for several minutes. Again mix and filter. Proceed by $(b)$ or $(c)$.

\section{(b) ANALYSIS BY LANE AND EYNON TITRATION AND THE MODIFIED NYNS}

Weigh out an amount of the original sample which contains about 1 to $1.5 \mathrm{~g}$ of reducing sugar. This will vary between about 7 and $10 \mathrm{~g}$. The concentration of sugar in the sample can be roughly gaged, if necessary, by refractometric examination of the juice and by assuming a total sugar purity of about 85 per cent. Hydrolyze in a $200-\mathrm{ml}$ flask, defecate, make to volume $0.2 \mathrm{ml}$ above the mark, and filter, as described under $(a)$. Titrate the filtrate directly against $25 \mathrm{ml}$ of mixed Soxhlet reagent according to Lane and Eynon's method. ${ }^{7}$ Apply a correction to the titer $(T)$ if titrations of standard solutions fail to show exact correspondence with Lane and Eynon's factors (RP426, p. 439).

Assuming that the ratio of levulose to total sugar is about 75 per cent, calculate from the total sugar titration the volume of the filtrate which contains about $75 \mathrm{mg}$ of levulose. Add this volume to $50 \mathrm{ml}$ of Ost's solution and add sufficient water to make $70 \mathrm{ml}$. Determine levulose as previously described (RP426, p. 425).

Calculate the ratio $(R)$ of levulose to total sugar by means of Table 25 (RP426, p. 444). Refer to Table 22 (RP426, p. 439) for the proper Lane and Eynon factor. Calculate sugars in the original sample by

$$
\begin{gathered}
\frac{F \times 20}{T \times \text { weight sample }}=\text { per cent total sugar } \\
R \times \text { per cent total sugar }=\text { per cent levulose. }
\end{gathered}
$$
(c) ANALYSIS BY LANE AND EYNON TITRATION AND TEMPERATURE COEFFICIENT
OF POLARIZATION

Weigh out a $50-\mathrm{g}$ sample, transfer to a $200-\mathrm{ml}$ Soxhlet flask, hydrolyze, and defecate as described under $(a)$. Make to volume 0.8 $\mathrm{ml}$ above the mark. Remove lead from the filtrate by addition of dry sodium oxalate or a mixture of dry oxalate and phosphate. Polarize at or near $20^{\circ} \mathrm{C} . \quad\left(=P_{1}\right)$ and at about $70^{\circ} \mathrm{C}$. in a water-jacketed polariscope tube, noting accurately the respective temperatures of polarization (RP426, p. 418).

Correct the high temperature polarization for the thermal expansion of the solution by

and calculate the per cent of levulose by

$$
P_{\text {obs. }}\left[1+0.00043\left(t_{2}-t_{1}\right)\right]=P_{2}
$$

$$
\frac{4\left(P_{2}-P_{1}\right)}{0.0344\left(t_{2}-t_{1}\right)}=\text { per cent levulose }
$$

7 J. Soc. Chem. Ind., vol. 42, p. 32, 1923. J. Assoc. Officıal Agri. Chem., vol. 9, p. 35, 1926. For correction to titer, see B. S. Jour. Research, vol. 8 (R P426), p. 420, 1932. 
valid for a $2-\mathrm{dm}$ polariscope tube. If a $4-\mathrm{dm}$ tube is used divide the result by 2 .

Pipette a volume of the filtrate which contains about 1 to $1.5 \mathrm{~g}$ of reducing sugar, make to $200 \mathrm{ml}$ and titrate against $25 \mathrm{ml}$ of Soxhlet's solution by Lane and Eynon's method. Calculate total sugar by

$$
\frac{F \times 20 \times 200}{T \times v \times 50}=\frac{F \times 80}{T \times v}=\text { per cent total sugar }
$$

in which $v$ is the volume diluted to $200 \mathrm{ml}$ for titration. The factor $F$ must be taken from the column in Table 22 (RP426, p. 439) which corresponds to the proper ratio of levulose to total sugar.

\section{(d) PURITY OF DIFFUSION OR PRESS JUICE}

The definition of purity of diffusion or press juice is to some extent arbitrary. The dry substance determination is necessarily made before the addition of the hydrolyzing agent, while the sugar analysis is made after such addition. There is therefore a change in the dry substance between the two operations. It would be possible to hydrolyze with some reagent, such as sulphuric acid, and remove it after hydrolysis with barium hydroxide. This procedure would not only be too tedious for routine analysis, but would yield the purity not of the original juice but of the defecated juice, since neutralization of the acid would be accompanied by defecation. It therefore seems advisable for practical purposes to define arbitrarily the purity as the ratio of levulose (or of total sugar) after hydrolysis to the apparent dry substance before hydrolysis. Such purity will of course be "apparent."

Dry substance determination of artichoke juices are most satisfactorily made by refractometric or densimetric estimation. A reference of such observation to Tables 18, 19, or 20 (RP426, pp. 437-438) yields "apparent" dry substance, since the tables are strictly valid only for pure levulose solutions. The dry substance can be determined by desiccation methods, but the latter are difficult because the end point of the drying is never sharply determinable. Moreover, the dry substance is still "apparent" with respect to the sugar analysis, for it consists of polysaccharides which take up water upon hydrolysis.

Having determined the apparent dry substance, weigh out a quantity of juice containing 1 to $1.5 \mathrm{~g}$ of total sugar and analyze as described under $(b)$, or 10 to $15 \mathrm{~g}$ and proceed as in $(c)$. Divide the percentage of levulose by percentage of dry substance to obtain the apparent purity.

\section{(e) NOTES}

The general methods described above can be applied to any plant material which contains polysaccharides similar in nature to those present in the Jerusalem artichoke, dahlia, or chicory. Only when the whole plant material is included in the sample is the allowance made for the volume of the marc.

Juices which have been hydrolyzed and defecated in preparation for the lime precipitation process can be analyzed by the methods described under $(b)$ or $(c)$, omitting the directions for hydrolysis. It is essential that calcium be completely removed by oxalate or oxalatephosphate mixture, because it interferes seriously with the reducing sugar analysis.

In order to facilitate the introduction of a $50-\mathrm{g}$ sample of pulped plant material into a $200-\mathrm{ml}$ flask it is convenient to make use of a 
brass funnel, the stem of which extends into and below the neck of the flask, and a plunger consisting of a solid brass cone with a rod attached to the smaller end.

Defecation with normal lead acetate is more complete in neutral or but slightly acid solution. The hydrochloric acid can be neutralized in the manner described if the agitation is sufficiently vigorous to avoid local alkalinity. If preferred an $8 \mathrm{~N}$ solution of potassium acetate can be substituted for the $\mathrm{NaOH}$. This solution can be conveniently prepared by neutralizing about $50 \mathrm{~g}$ of $\mathrm{KOH}$ with about 47 to $50 \mathrm{ml}$ of standardized glacial acetic acid and completing the volume to $100 \mathrm{ml}$.

An approximate determination of levulose in artichokes can be made by applying the Mathews formula. The filtrate from a 50-g sample is polarized directly and an aliquot volume titrated for reducing sugars. From the observed data total sugar and levulose are calculated in the manner described in RP426, p. 433. The errors in the ratio which result from the application of the Mathews formula to artichoke and dahlia juices are to be ascribed mainly to the presence of the dextrorotatory nonreducing difructose anhydrides. In Tables 1 and 2 are given the true and the Mathews ratio, the deviation of the latter averaging about 3.0 per cent of the quantity measured.

The addition of $3 \mathrm{ml}$ of $8 \mathrm{~N} \mathrm{HCl}$ is sufficient for hydrolysis if the sample contains not in excess of $19 \mathrm{~g}$ of dry substance. If greater weights of dry substance are present add $4 \mathrm{ml}$.

\section{EXHAUSTED PULP AND PULP WATER (RAPID METHOD)}

The control of the diffusion process for the extraction of juice from artichokes or similar plants requires a rapid analysis of the pulp and pulp water from the last cell of the battery as soon after its discharge as possible.

Grind the pulp sample through a food chopper and express the juice by means of a tincture press or, preferably, a hydraulic press. Pipette $100 \mathrm{ml}$ into a $200-\mathrm{ml}$ volumetric flask. Add $4 \mathrm{ml}$ of $8 \mathrm{~N} \mathrm{HCl}$ and immerse the flask in a boiling-water bath for four minutes. Remove from the bath and cool rapidly. Add $1 \mathrm{ml}$ of saturated lead acetate and $4 \mathrm{ml}$ of $8 \mathrm{~N} \mathrm{NaOH}$. Make to volume, filter, and titrate by Lane and Eynon's method against 25 or $10 \mathrm{ml}$ of mixed Soxhlet solution according to the concentration of sugar.

$$
\frac{F \times 0.2}{T}=\text { grams of reducing sugar in } 100 \mathrm{ml}
$$

Pipette $175 \mathrm{ml}$ of pulp water into a $200-\mathrm{ml}$ flask and add $4 \mathrm{ml}$ of $8 \mathrm{~N} \mathrm{HCl}$. Immerse in boiling water and proceed as described in the previous paragraph.

$$
\frac{F \times 0.114}{T}=\text { grams of reducing sugar in } 100 \mathrm{ml}
$$

If the concentration of sugar is too low for titration by the standard Lane and Eynon methods, titrate against one of the dilute Soxhlet reagents by the method described on page 603 . 


\section{LEVULATE SLUDGE}

Besause of the instability of the reducing sugars in the alkaline medium in which calcium levulate is precipitated the levulate sludge must be sampled and neutralized without delay.

\section{(a) TOTAL $\mathrm{CaO}$}

Weigh out $20 \mathrm{~g}$ of the thoroughly mixed sludge and wash into a porcelain casserole. Add $20 \mathrm{ml}$ of Steffen's $\mathrm{HNO}_{3}$, stir with a glass rod until completely dissolved, and boil for three to five minutes. Cool and titrate to a faint pink with Steffen's $\mathrm{NaOH}$ (phenolphthalein)

$$
\text { Titer } \div 4=\text { per cent } \mathrm{CaC}
$$

\section{(b) TOTAL REDUCING SUGAR}

Weigh out $15 \mathrm{~g}$ of the sample, wash into a porcelain casserole, and titrate to slight acidity with Steffen's HCl. Add a volume of Steffen's potassium oxalate-phosphate mixture equal to the volume of the Steffen's $\mathrm{HCl}$ plus a sufficient quantity to precipitate any neutral calcium which may have been introduced with the defecated juice. Wash into a $200 \mathrm{ml}$ volumetric flask, make to volume, and add by means of a graduated pipette an excess of water equal to the volume of the precipitate. (See p. 604.) Filter and titrate directly against $25 \mathrm{ml}$ of mixed Soxhlet solution by Lane and Eynon's method for total reducing sugars. Calculate by

$$
\frac{4 \times F}{3 \times T}=\text { per cent reducing sugar }
$$

in which $F$ is Lane-Eynon's factor and $T$ the corrected titer.

\section{(c) LEVULOSE}

In most instances the ratio of levulose to total reducing sugar will have been determined previous to the precipitation process. If so, the known ratio can be applied to the percentage of total reducing sugar to compute the percentage of levulose. The latter can be determined by analysis of the above filtrate by taking a volume containing about $75 \mathrm{mg}$ of levulose and proceeding by the modified Nyns method as described in RP426, page 425 . Calculate the ratio, $R$, as described in $R P 426$, page 444 .

$R \times$ per cent total sugar $=$ per cent levulose

\section{LEVULATE CAKE}

(a) TOTAL $\mathrm{CaO}$

Weigh out $10 \mathrm{~g}$ of the sample and wash into a porcelain casserole. Add an excess (usually $25 \mathrm{ml}$ ) of Steffen's $\mathrm{HNO}_{3}$. Stir with a glass rod until dissolved, place over a flame, and allow it to boil from three to five minutes. Add a few drops of phenolphthalein and titrate to a faint pink with Steffen's $\mathrm{NaOH}$. 


$$
\text { Titer } \div 2=\text { per cent } \mathrm{CaO}
$$

(b) TOTAL SUGAR AND LEVULOSE

Weigh out $20 \mathrm{~g}$ of the sample, wash into a porcelain casserole, and titrate to slight acidity with Steffen's $\mathrm{HCl}$ (phenolphthalein). Wash into a $200 \mathrm{ml}$ volumetric flask. Add a volume of Steffen's oxalatephosphate mixture slightly in excess of the determined volume of Steffen's $\mathrm{HNO}_{3}$ which was required for the $\mathrm{CaO}$ determination. Make to volume and add an excess of water equal to the volume of the precipitate, that is, $0.065 \times$ milliliters of Steffen's reagents used.

Polarize the filtrate, preferably in a $400 \mathrm{~mm}$ tube, at or near $20^{\circ} \mathrm{C}$., recording the temperature of observation. The negative polarization of levulose is enhanced in the presence of $\mathrm{KCl}, 1 \mathrm{~g}$ in $100 \mathrm{ml}$ increasing it in the negative sense by 0.59 per cent. Since there is formed $0.1332 \mathrm{~g}$ of KCl for each milliliter of Steffen's reagent added, diminish the negative polarization by 0.078 per cent of its value for each milliliter of Steffen's reagent used.

Pipette $50 \mathrm{ml}$ of the filtrate into a $200 \mathrm{ml}$ flask, make to volume, and titrate against $25 \mathrm{ml}$ of Soxhlet's solution.

From the corrected polarization and the corrected titer calculate the Mathews ratio in the manner described on p. 440, RP426, remembering that the polarization, $P$, in the formula refers to the rotation in a $2 \mathrm{dm}$ column. Calculate by

and

$$
\frac{F \times 4}{T}=\text { per cent total sugar, }
$$

$R \times$ per cent total sugar $=$ per cent levulose

\section{WASTE WATER}

(a) $\mathrm{CaO}$

Weigh out $100 \mathrm{~g}$ of the sample, wash into a porcelain casserole, and titrate with Steffen's HCl (phenolphthalein). Save the solution for (b) and $(c)$.

$$
\text { Titer } \div 20=\text { per cent } \mathrm{CaO}
$$

(b) TOTAL SUGAR

Wash the titrated solution into a $200 \mathrm{ml}$ volumetric flask and add a volume of Steffen's oxalate-phosphate mixture equal to the titer for $\mathrm{CaO}$. If the solution is derived from a juice which has been hydrolyzed with $\mathrm{H}_{2} \mathrm{SO}_{4}$ and defecated with lime, add an additional $15 \mathrm{ml}$ of the oxalate-phosphate mixture. The calcium must be completely removed. Make to volume and add an excess of water equal to the volume of the precipitate; that is, $0.065 \times$ milliliters of Steffen's reagent. From the filtrate pipette a volume containing about $1 \mathrm{~g}$ of total sugar into a $200 \mathrm{ml}$ volumetric flask, make to volume, and titrate against $25 \mathrm{ml}$ of mixed Soxhlet reagent.

\section{(c) LEVULOSE}

Assuming a ratio of levulose to total sugar of 35 per cent, compute the volume of the original filtrate which contains about $75 \mathrm{mg}$ of "apparent" levulose, add this volume to $50 \mathrm{ml}$ of Ost's reagent, make to $70 \mathrm{ml}$, and proceed as directed on page $425, \mathrm{RP} 426$. Cal- 
culate the ratio of levulose to total sugar in the usual way by referring to Table 22 (RP426, p. 444) and find the total sugar and levulose by the following formulas:

$$
\frac{40 \times F}{T \times v}=\text { per cent total sugar }
$$

where $F$ is Lane and Eynon's factor, $T$ is the Lane and Eynon titer, and $v$ is the volume of solution which was diluted to $200 \mathrm{ml}$ for the titration:

\section{Per cent total sugar $\times R=$ per cent levulose}

Some uncertainty is introduced by assuming a value for the neutral calcium which is precipitated. The variations from the value given above will, in general, be within the analytical accuracy. If desired, the calcium can be precipitated by dry sodium oxalate and the uncertainty avoided.

\section{EVAPORATOR LIQUORS}

The levulose solutions which are prepared by carbonation of the levulate cake are of relatively high purity. After filtration from the calcium carbonate they are freed from calcium bicarbonate by evaporation or other means and filtered. At this point an analysis is of significance in determining the completeness of the separation of levulose from its impurities.

It has already been shown that for artichoke juices the Mathews ratio differs but slightly from the true ratio, a fact which indicates that the optically active substances in the juice are mainly levulose and dextrose. It follows, then, that in the purified liquors from which most of the impurities have been removed the Mathews ratio will approach the true ratio very closely. Inasmuch as the analytical operations contributing to the determination of the Mathews ratio are far more precise and reproducible than those depending upon Nyns's method, it is to be recommended that the levulose purity of high purity liquors be determined on the basis of the Mathews ratio solely.

(a) DRY SUBSTANCE

Determine dry substance by measurement of density, referring the observation to Tables 18 or 19 (RP426, p. 437), or by refractometer reading, referring to Table 20 (RP426). If the sirup has too high a concentration for the polarization which is to follow, it must be diluted to below 17.2 per cent for a $20^{\circ} \mathrm{C}$. polarization, or below 17.9 per cent for $25^{\circ}$ polarization. In this case the dry substance measurement must be repeated for the diluted solution, or a weighed amount of the concentrated solution must be diluted with a weighed amount of water.

\section{(b) DIRECT POLARIZATION AND APPARENT PURITY}

Polarize the diluted solution directly, recording the temperature of observation accurately. From this observation and the percentage of dry substance of the solution the "apparent" purity can be calculated by assuming that all optically active material is levulose. Correct the direct polarization to either $20^{\circ}$ or $25^{\circ} \mathrm{C}$. by assuming an expansion coefficient of 0.00043 and a polarization temperature 
coefficient of $0.0344^{\circ} \mathrm{S}$. for each gram of levulose per degree change of temperature. Correct for concentration by Table 21 (RP426, p. 439). Multiply the normal weight $\left(18.407 \mathrm{~g}\right.$ at $20^{\circ} \mathrm{C}$. or $19.003 \mathrm{~g}$ at $25^{\circ}$ C.) by the direct polarization and divide by the number of grams of dry substance in $100 \mathrm{ml}$. (See below.)

\section{(c) TOTAL SUGAR}

Compute from the polarization or dry substance analysis the volume of solution containing about $1 \mathrm{~g}$ of total sugar. Transfer this volume to a $200-\mathrm{ml}$ volumetric flask, make to volume, and titrate against $25 \mathrm{ml}$ of mixed Soxhlet reagent.

\section{(d) TRUE PURITY}

From the direct polarization and reducing sugar titration compute the product $P \times T / D$ and determine the ratio of levulose to total sugar by reference to Table 24 (RP426, p. 442; see also example on p. 440). The true purity of the sample is

$$
\frac{F \times R \times D}{T \times S \times 10}=\text { per cent purity }
$$

in which $F$ is Lane and Eynon's factor, $R$ the Mathews ratio, $T$ the corrected titer, $D$ the number of volumes to which the solution polarized was diluted for titration, and $S$ the grams of dry substance in $100 \mathrm{ml}$ of the solution polarized. The latter is determined by multiplying the percentage of dry substance by the density as given in Table 18 (RP426, p. 437). This product is the weight of dry substance in vacuo and for precise work should be diminished by 0.11 per cent of its value to give its weight in air with brass weights.

\section{HONEY AND VARIOUS FRUITS}

The methods of selective levulose analysis are applicable to any product containing levulose. In order to illustrate further possible applications, we have analyzed samples of honey and such fruits as were immediately available.

The samples of honey were supplied by the Bee Culture Laboratory, of the United States Department of Agriculture. Dry substance determinations were made by C. F. Snyder, of this bureau, by refractometer readings referred to Table 20 (RP426, p. 438). The samples were prepared for analysis by weighing out $20 \mathrm{~g}$ and washing into $200-\mathrm{ml}$ volumetric flasks. The solutions were clarified satisfactorily by addition of alumina cream. Sucrose was estimated by determining polarizations before and after inversion with invertase. Both the original and inverted solutions were subjected to a complete sugar analysis by the general procedure outlined on pages 604-606. Before calculating the Mathews ratio, the rotation of the sucrose was deducted from the direct polarization.

The analytical data are assembled in Table 5. This group of samples showed a ratio of levulose to total sugar not greatly in excess of 50 per cent; the ratio is therefore not appreciably altered by the inversion of the sucrose. The deviation of the Mathews ratio from the true ratio has been solved by formula (3) under the arbitrary assumption that the deviation is due to dextrins. If a specific rotation of 
$+150^{\circ}$ C. ${ }^{8}$ is assigned to these substances, the constant $c$ in formula (2) acquires a value of 11.5 . It is apparent from columns 8 and 13 that these substances occur in all the samples analyzed and that normal nectar honeys contain a mean of about 4.6 per cent. Obviously, if honey were adulterated with any considerable quantity of invert sugar, the deviation of the Mathews ratio from the true ratio will diminish. The suggestion is made that this method of grouping these substances under the designation "apparent dextrins" may be useful in the critical examination of honey. In the honey dew and the melezitose honey the quantity of apparent dextrins becomes very large. The melezitose honey shows no significant change in ratio or in the apparent dextrins before and after inversion, indicating that melezitose is unaffected by invertase. In confirmation of this fact, a sample of pure melezitose showed no change in polarization after treatment with invertase. The total carbohydrates in the melezitose honey fall far short of the total dry substance. This arises from the fact that we ascribed a specific rotation of +150 to the undertermined carbohydrates. If we make the assumption that the total carbohydrate purity is 98.2 per cent (the mean of the remaining honeys) and assign a specific rotation of +150 to the dextrins and +87.8 to melezitose, we can solve simultaneously for the two latter substances. Such a solution yields values of 3.9 per cent dextrins and 20.2 per cent melezitose.

The samples of fruit were obtained by purchase from commercial sources. No attempt was made to secure representative samples, since the purposes of the present article were merely to illustrate the applicability of the methods of analysis. Although some of the fruits were "out of season" at the time of the analysis (March), they were in every case firm and sound.

The analyses refer only to the press juice which was obtained by extraction of the comminuted sample in a small tincture press. Considerable difficulty was encountered in the filtration of the solution after defecation with normal lead acetate, but this was overcome in some cases by sedimentation in a centrifugal machine. The solutions from the deeply colored fruits in some cases remained discolored after defecation, but were completed bleached by one or two drops of a $0.5 \mathrm{~N}$ sulphur dioxide solution.

One hundred grams of the sample of press juice was transferred to a $200 \mathrm{ml}$ flask, defecated with normal lead acetate, and filtered or sedimented. Lead was removed by adding a mixture of dry sodium phosphate and sodium oxalate. Sucrose was determined by the invertase method, and total sugars and levulose by the methods previously described. The ratio of levulose to total sugar as determined by the Mathews formula was derived from the titer and from the direct polarization corrected for the rotation of sucrose.

The analytical data are shown in Table 6 . It is noteworthy that all of the fruits examined, except the cranberries, showed an excess of levulose, slight in many cases, but rising to great predominance in apples and pears. The deviation of the Mathews ratio from the true ratio as shown in column 8 is small in all cases except the peach and the cranberry in which it assumes large negative values. This indicates the presence of a levorotatory substance.

${ }^{8}$ Browne's Handbook of Sugar Analysis, p. 523. John Wiley \& Sons, New York, 1912. 
TABLE 5.-Analyses of honeys

\begin{tabular}{|c|c|c|c|c|c|c|c|}
\hline \multirow{2}{*}{$\begin{array}{l}\text { Principal floral source of } \\
\text { honey }\end{array}$} & \multicolumn{7}{|c|}{ Original honey } \\
\hline & $\begin{array}{l}\text { Dry } \\
\text { sub- } \\
\text { stance }\end{array}$ & Sucrose & $\begin{array}{l}\text { Reduc- } \\
\text { ing } \\
\text { sugars }\end{array}$ & $\begin{array}{l}\text { Levu- } \\
\text { lose }\end{array}$ & $\begin{array}{l}\text { Ratio: } \\
\text { Levulnse } \\
\begin{array}{c}\text { reducing } \\
\text { sugar }\end{array}\end{array}$ & $\begin{array}{l}\text { Mathews } \\
\text { ratio: } \\
\text { Levulose } \\
\begin{array}{l}\text { reducing } \\
\text { sugar }\end{array}\end{array}$ & $\begin{array}{l}\text { Appar- } \\
\text { ent } \\
\text { dextrins }\end{array}$ \\
\hline $\begin{array}{l}\text { Sumac } \\
\text { White clover } \\
\text { Buckwheat } \\
\text { Blend No. } 1 .\end{array}$ & \begin{tabular}{|r|} 
Per cent \\
82.54 \\
82.42 \\
81.08 \\
82.42
\end{tabular} & $\begin{array}{r}\text { Per cent } \\
3.26 \\
1.69 \\
.44 \\
1.61\end{array}$ & $\begin{array}{c}\text { Per cent } \\
72.13 \\
76.09 \\
75.53 \\
78.69\end{array}$ & $\begin{array}{r}\text { Per cent } \\
37.53 \\
39.26 \\
38.97 \\
42.02\end{array}$ & $\begin{array}{r}\text { Per cent } \\
51.9 \\
51.6 \\
51.6 \\
53.4\end{array}$ & $\begin{array}{r}\text { Per cent } \\
43.2 \\
46.9 \\
46.3 \\
50.3\end{array}$ & $\begin{array}{r}\text { Per cent } \\
5.81 \\
3.32 \\
3.71 \\
2.26\end{array}$ \\
\hline $\begin{array}{l}\text { Alfalfa } \\
\text { Sourwood } \\
\text { Fireweed } \\
\text { Gallberry }\end{array}$ & $\begin{array}{l}85.68 \\
82.46 \\
84.48 \\
83.24\end{array}$ & $\begin{array}{l}4.73 \\
1.41 \\
4.54 \\
.83\end{array}$ & $\begin{array}{l}76.05 \\
69.17 \\
74.76 \\
73.20\end{array}$ & $\begin{array}{l}39.63 \\
38.94 \\
40.97 \\
41.14\end{array}$ & $\begin{array}{l}52.1 \\
56.3 \\
54.8 \\
56.2\end{array}$ & $\begin{array}{l}44.8 \\
44.8 \\
47.4 \\
48.5\end{array}$ & $\begin{array}{l}5.15 \\
7.99 \\
5.12 \\
5.21\end{array}$ \\
\hline $\begin{array}{l}\text { Goldenrod } \\
\text { Blend No. } 2 \text { (incense cedar) } \\
\text { Honey dew } \\
\text { Melezitose honey }\end{array}$ & $\begin{array}{l}82.16 \\
84.84 \\
86.44 \\
83.50\end{array}$ & $\begin{array}{r}.68 \\
1.65 \\
2.90 \\
.30\end{array}$ & $\begin{array}{l}77.08 \\
77.81 \\
61.05 \\
57.61\end{array}$ & $\begin{array}{l}39.93 \\
39.92 \\
28.95 \\
32.57\end{array}$ & $\begin{array}{l}51.8 \\
51.3 \\
47.4 \\
56.5\end{array}$ & $\begin{array}{l}47.0 \\
45.8 \\
11.4 \\
27.0\end{array}$ & $\begin{array}{r}3.43 \\
3.97 \\
20.43 \\
15.70\end{array}$ \\
\hline
\end{tabular}

\begin{tabular}{|c|c|c|c|c|c|}
\hline \multirow[b]{2}{*}{ Principal floral source of honey } & \multicolumn{5}{|c|}{ Honey after invertase inversion } \\
\hline & $\begin{array}{c}\text { Reducing } \\
\text { sugars }\end{array}$ & Levulose & $\begin{array}{l}\text { Ratio: } \\
\text { Levulose } \\
\text { reducing } \\
\text { Sugar }\end{array}$ & $\begin{array}{l}\text { Mathews } \\
\text { ratio: } \\
\text { Levulose } \\
\text { reducing } \\
\text { sugar }\end{array}$ & $\begin{array}{l}\text { Apparent } \\
\text { dextrins }\end{array}$ \\
\hline 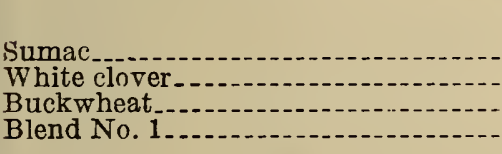 & $\begin{array}{r}\text { Per cent } \\
75.50 \\
77.70 \\
75.67 \\
79.11\end{array}$ & $\begin{array}{r}\text { Per cent } \\
38.96 \\
40.09 \\
39.12 \\
41.37\end{array}$ & $\begin{array}{r}\text { Per cent } \\
51.6 \\
51.6 \\
51.7 \\
52.3\end{array}$ & $\begin{array}{r}\text { Percent } \\
43.4 \\
46.9 \\
46.3 \\
50.4\end{array}$ & $\begin{array}{r}\text { Per cert } \\
5.75 \\
3.39 \\
3.80 \\
1.40\end{array}$ \\
\hline $\begin{array}{l}\text { Alfalfa } \\
\text { Sourwood } \\
\text { Fireweed } \\
\text { Gallberry }\end{array}$ & $\begin{array}{l}80.45 \\
70.27 \\
79.01 \\
74.13\end{array}$ & $\begin{array}{l}41.11 \\
39.56 \\
43.22 \\
41.74\end{array}$ & $\begin{array}{l}51.1 \\
56.3 \\
54.7 \\
56.3\end{array}$ & $\begin{array}{l}45.1 \\
43.9 \\
47.5 \\
48.3\end{array}$ & $\begin{array}{l}4.49 \\
8.07 \\
5.28 \\
5.49\end{array}$ \\
\hline $\begin{array}{l}\text { Goldenrod } \\
\text { Blend No.2 } \\
\text { Honey dew (incense cedar) } \\
\text { Melezitose honey }\end{array}$ & $\begin{array}{l}77.32 \\
79.23 \\
62.78 \\
57.96\end{array}$ & $\begin{array}{l}40.52 \\
40.50 \\
30.62 \\
33.26\end{array}$ & $\begin{array}{l}52.4 \\
51.5 \\
48.8 \\
57.4\end{array}$ & $\begin{array}{l}47.1 \\
45.8 \\
12.5 \\
27.0\end{array}$ & $\begin{array}{r}3.80 \\
4.20 \\
21.17 \\
16.27\end{array}$ \\
\hline
\end{tabular}

TABLE 6.-Analyses of fruits

\begin{tabular}{|c|c|c|c|c|c|c|c|c|}
\hline Fruit & \begin{tabular}{|} 
Dry \\
sub- \\
stance \\
by re- \\
fractem- \\
eter
\end{tabular} & Sucrose & $\begin{array}{l}\text { Reduc- } \\
\text { ing } \\
\text { sugars }\end{array}$ & $\begin{array}{l}\text { Levu- } \\
\text { lose }\end{array}$ & $\begin{array}{l}\text { Ratio: } \\
\text { Levulose } \\
\text { reducing } \\
\text { sugar }\end{array}$ & $\begin{array}{l}\text { Mathews } \\
\text { ratio: } \\
\text { Levulose } \\
\begin{array}{c}\text { reducing } \\
\text { sugar }\end{array}\end{array}$ & $\Delta R$ & $\begin{array}{l}\text { Total } \\
\text { sugar } \\
\text { purity }\end{array}$ \\
\hline $\begin{array}{l}\text { Peach, "Old Gold", } \\
\text { Apple, "Delicious"-- } \\
\text { Pear, "D'Anjou" } \\
\text { Lemon } \\
\text { Orange }\end{array}$ & $\begin{array}{r}\text { Per cent } \\
16.50 \\
13.14 \\
17.06 \\
8.33 \\
12.07\end{array}$ & $\begin{array}{r}\text { Per cent } \\
8.62 \\
1.80 \\
1.24 \\
.40 \\
4.50\end{array}$ & \begin{tabular}{|c} 
Per cent \\
3.17 \\
9.63 \\
9.99 \\
2.03 \\
5.07
\end{tabular} & $\mid \begin{array}{c}\text { Per cent } \\
1.82 \\
6.58 \\
8.58 \\
1.07 \\
2.65\end{array}$ & $\begin{array}{r}\text { Per cent } \\
57.4 \\
65.3 \\
88.9 \\
52.9 \\
52.2 \\
\end{array}$ & $\begin{array}{r}\text { Per cent } \\
63.8 \\
69.8 \\
86.7 \\
51.8 \\
51.7\end{array}$ & $\begin{array}{r}\text { Per cent } \\
-6.4 \\
-1.5 \\
2.2 \\
1.1 \\
.5\end{array}$ & $\begin{array}{r}\text { Per cent } \\
71.5 \\
87.0 \\
65.8 \\
29.2 \\
79.3\end{array}$ \\
\hline $\begin{array}{l}\text { Grapefruit } \\
\text { Grapes, "Almeria" } \\
\text { Strawberry } \\
\text { Cranberry } \\
\text { Tomato }\end{array}$ & $\begin{array}{r}13.84 \\
18.05 \\
7.63 \\
3.93 \\
4.67\end{array}$ & $\begin{array}{r}4.03 \\
.19 \\
.82 \\
.24 \\
0\end{array}$ & $\begin{array}{r}6.05 \\
16.28 \\
4.09 \\
5.18 \\
2.79\end{array}$ & $\begin{array}{r}3.17 \\
8.32 \\
2.20 \\
.82 \\
1.58\end{array}$ & $\begin{array}{l}52.5 \\
51.1 \\
53.8 \\
15.8 \\
57.7\end{array}$ & $\begin{array}{l}51.3 \\
48.6 \\
51.2 \\
30.5 \\
56.3\end{array}$ & $\begin{array}{r}1.2 \\
2.5 \\
2.6 \\
-14.7 \\
1.4\end{array}$ & $\begin{array}{l}72.8 \\
91.2 \\
66.4 \\
54.6 \\
59.7\end{array}$ \\
\hline
\end{tabular}

Washington, August 13, 1932.

$$
\text { 141809-32- } 3
$$

